Arthroskopie 2018 $31: 175$

https://doi.org/10.1007/s00142-018-0209-7

Online publiziert: 23. März 2018

(c) Springer Medizin Verlag GmbH, ein Teil von Springer Nature 2018

CrossMark

Jiří Lubojacký

Orthopaedic and traumatologic dpt., Silesian Hospital, Opava, Tschechien

\title{
Zu Reverse-Hill-Sachs-Läsion bei dorsal verhakter Schulterluxation
}

\section{Leserbrief zu}

J. Theopold, P. Hepp (2018) Reverse-Hill-

Sachs-Läsion bei dorsal verhakter

Schulterluxation. Arthroskopie 1:9-20. https://

doi.org/10.1007/s00142-017-0170-x

Dear colleagues,

I read the article on "Reverse-Hill-Sachs lesion in dorsally locked shoulder dislocation" with interest.

As part of the "Tips and tricks" section, I recommend an easy manoeuvre for conservative reposition. The displaced arm is simply abducted, which unlocks the humeral head and leads to its reposition. The procedure does not need assistance and it is successful without anaesthesia in acute cases.

Our sample of 10 cases (including bilateral neglected displacement) was published in the Czech national nonindexed journal Ortopedie [1] (the next 3 cases have now been managed since that time).

With regards

Jiří Lubojacký

\section{Korrespondenzadresse}

Dr. J. Lubojacký

Orthopaedic and traumatologic dpt., Silesian Hospital

Olomoucka 86, 74601 Opava, Tschechien jirilub@gmail.com

Interessenkonflikt. J. Lubojacký gibt an, dass kein Interessenkonflikt besteht.

\section{Literatur}

\section{Posterior dislocation of the glenohumeral joint in field practice. Ortopedie 2014: http://medakta. cz/cislo.php?casopis=ortopedie\&rocnik=2014\& cislo=4\#695.Zugegriffen: 18. März 2018}

